\title{
HUBUNGAN ANTARA GAYA PENGASUHAN ORANG TUA TIPE ENABLING DAN CONSTRAINING DENGAN KOMITMEN DAN PEMBENTUKAN STATUS IDENTITAS KEBERAGAMAAN REMAJA AKHIR
}

\author{
Endin Nasrudin \\ Fakultas Psikologi UIN Sunan Gunung Djati Bandung
}

\begin{abstract}
A significant correlation was found, between the enabling parental style to exploration in the domain of religion identity status; between the anabling parental style to commitment, and between the constraining parental style to exploration. No relationship was found between the constraining parental style and commitment in the domain of religious identity status. Suggestion for further research would be to identity other variables connected with identity status in the religion domain.
\end{abstract}

Keywords: Enabling, constraining, religion identity

\section{Pendahuluan}

Terkait dengan perencanaan identitas dalam bidang agama, biasanya remaja mulai menyangsikan keyakinan ajaran agama yang diajarkan oleh orang tua atau lingkungan keluarganya dengan cara mempertanyakan kembali keyakinan dan ajaran agama yang diyakininya. Menurut Wagner (Hurlock, 1999), masa remaja ditandai dengan "masa kesangsian religius". Upaya mencari informasi, mempertanyakan kembali serta mencari tahu tentang masalah-masalah agama merupakan bentuk eksplorasi yang dilakukan oleh ramaja dalam upaya mencapai status identitas dalam bidang agama. Menurut Marcia (1980), pada usia remaja akhir, individu diharapkan dapat menyelesaikan periode pencarian identitas diri.
Perjuangan mengatasi kritis identitas pada remaja tidak terlepas dari latar belakang kehidupan keluarganya. Menurut Hauser (Archer, 1994) gaya pengasuhan enabling mendukung kebebasan anak untuk melakukan eksplorasi seluas-luasnya dan menentukan komitmen dari hasil eksplorasi tersebut secara mandiri, sedangkan gaya pengasuhan constraining menghambat bagi upaya eksplorasi anak dan memantapkan komitmennya dalam bidang agama.

Dalam menemukan jawaban terhadap pencarian (krisis) identitas bidang agama, sangat mungkin sebagian remaja mengalami kebingungan dan kekaburan mengenai pemahaman, penghayatan dan pengamalan ajaran agama yang selama ini telah diyakininya sebagai warisan penanaman 
keyakinan beragama dari orang tua atau orang dewasa lainnya.

\section{Rumusan Masalah}

Masalah-masalah yang menjadi fokus kajian ini dirumuskan sebagai berikut:

1) Adakah hubungan antara gaya pengasuhan orang tua yang enabling dengan eksplorasi dalam pembentukan status identitas bidang agama pada mahasiswa IAIN Sunan Gunung Djati Bandung?;

2) Adakah hubungan antara gaya pengasuhan orang tua yang enabling dengan komitmen dalam pembentukan status identitas bidang agama pada mahasiswa IAIN Sunan Gunung Djati Bandung?;

3) Adakah hubungan antara gaya pengasuhan orang tua yang constraining dengan eksplorasi dalam pembentukan status identitas bidang agama pada mahasiswa IAIN Sunan Gunung Djati Bandung?;

4) Adakah hubungan antara gaya pengasuhan orang tua yang constraining dengan komitmen dalam pembentukan status identitas bidang agama pada mahasiswa IAIN Sunan Gunung Djati Bandung?;

5) Bagaimana gambaran/profil pencapaian status identitas bidang agama pada mahasiswa IAIN Sunan Gunung Djati Bandung?

\section{Kajian Pustaka}

Erikson (1980) menjelaskan bahwa, masa remaja ditandai dengan upaya pencarian identitas diri, yakni usaha untuk menjelaskan siapa dirinya, apakah peran dan tanggung jawabnya dalam masyarakat dan kemana tujuan hidupnya. Menurut Marcia (1980) remaja akhir (18-22 tahun) diharapkan mampu menyelesaikan periode pencarian identitas diri. Tuntutan terbentuknya identitas diri, terbentuknya identitas diri akan memunculkan eksplorasi dan komitmen pada remaja dalam domaindomain agama, pekerjaan, pendidikan, dan relasi antar jenis kelamin.

Menurut Erikson (dalam Mussen, 1989), identitas merefleksikan suatu perasaan akan konsisten diri, dimana identitas individu tersebut menggambarkan suatu integrasi dari kebutuhan, kemampuan, tujuan dan nilai-nilai yang relatif menyeluruh dan konsisten sepanjang waktu.

Pembentukan status identitas bidang agama berkaitan dengan kemampuan individu untuk mempertimbangkan secara luas dan mendalam terhadap nilai-nilai, kebutuhan-kebutuhan dan berbagai pengalaman keagamaan yang diperolehnya dalam menghayati dan mengamalkan aktivitas keberagamaannya. Pertimbangan yang luas dan mendalam terhadap masalahmasalah agama seperti yang dikatakan oleh Wagner (dalam Hurlock, 1993: 222), bukan berarti remaja agnostik atau atheis, melainkan karena remaja ingin menerima agama sebagai sesuatu yang bermakna 
berdasarkan keinginan mereka untuk mandiri dan bebas menentukan keputusankeputusan mereka sendiri.

Terkait dengan pencarian status identitas diri itu, Marcia (1993) mengartikan eksplorasi dalam bidang agama sebagai usaha individu untuk mengkaji, memahami, mendalami kembali (reidentification, redefinition) terhadap keyakinan ajaran agama yang dianutnya melalui berbagai aktivitas yang dilakukan dengan seluruh kemampuan akal, pikiran dan seluruh potensi yang dimilikinya untuk memperoleh suatu pemahaman yang baik dan menyeluruh. Sedangkan komitmen diartikan sebagai keterikatan, keteguhan dan kesetiaan terhadap keputusan pilihan yang telah diambil menyangkut keyakinan ajaran agama yang diyakininya dengan sepenuh hati, dimana semua itu diperoleh melalui proses pengambilan keputusan yang mantap serta didasari oleh pertimbangan pemikiran yang matang.

Berdasarkan atas kategori tinggi rendahnya tingkat eksplorasi dan komitmen, Orlofsky (dalam Marcia, 1993: 106) mengidentifikasi status identitas (termasuk dalam domain agama) atas empat macam sebagai berikut:

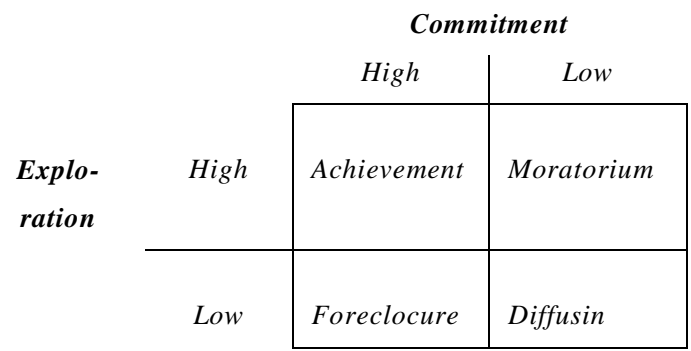

Gambar 1. Paradigma Status Identitas

Modifilasi Orlofsky
1) Identity Achievement. Status identitas ini menunjukkan bahwa individu telah mampu mengarahkan dirinya sendiri dan telah merasa puas dengan keyakinan-keyakinan dan tujuan-tujuan yang telah ditetapkannya. Hal ini menunjukkan bahwa sesungguhnya individu pada tahap ini telah melaui proses eksplorasi dari berbagai alternatif dengan sebaik-baiknya, dan juga telah mampu membuat suatu komitmen yang kuat berdasarkan nilai-nilai yang ada pada mereka serta menunjukkan komitmen dalam bentuk suatu tingkah laku nyata;

2) Identity Moratorium. Status identitas ini menggambarkan bahwa sesungguhnya individu telah melalui suatu proses eksplorasi, akan tetapi individu tersebut masih belum begitu jelas komitmennya. Individu pada status ini mempunyai kecenderungan masih terikat pada konsepkonsep sebelumnya atau masih adanya kebergantungan terhadap konsep-konsep sebelumnya. Individu yang berada pada status ini digambarkan sebagai individu yang asyik dengan dirinya sendiri; ia berusaha untuk melakukan kompromi antara tuntutan sosial dan kemampuan dirinya sendiri. Apabila mereka pada status ini memperoleh banyak kesempatan untuk mencari, mendapatkan pengalaman, dan mencoba peran-peran yang berbeda-beda, maka mereka akan dapat mengembangkan identitas dirinya lebih baik dan mencapai suatu komitmen. Tetapi sebaliknya, apabila tidak dapat mengembangkan dirinya dengan 
baik maka justru akan memasuki identitas difusi;

3) Identitiy Foreclosure. Pada status ini individu digambarkan sebagai seorang yang sedikit atau kurang melakukan eksplorasi, tetapi individu tersebut telah menetapkan suatu komitmen berdasarkan nilai-nilai yang telah diperoleh dari orang tuanya, gurunya atau, masyarakat yang diperoleh sejak masih kecil. Kepastian tentang arah pilihan yang ditetapkan biasanya berdasarkan pada nilai otoritas yang dianutnya dan dilatarbelakangi berbagai pengalaman dari orang tuanya dalam mendidik dan mengarahkan yang acapkali cenderung berlaku kaku dan bersifat dogmatis;

4) Identity Diffusion. Pada status ini, individu digambarkan sebagai seorang yang tidak mau melakukan eksplorasi, dan juga tidak mau melakukan komitmen pribadinya secara jelas. Keyakinan diri individu ini biasanya sudah dipengaruhi oleh orang lain. Mereka tidak aktif melakukan usaha untuk mengevaluasi diri, mencari tahu dan tidak mau mempertimbangkan option/alternatif lain. Biasanya individu seperti ini gampang dipengaruhi "kemana angin kuat mempengaruhinya ke situlah arahnya". Remaja dalam posisi seperti ini sangat berbahaya, apabila yang mengendalikan adalah orang-orang yang tidak baik maka remaja tersebut akan menjadi tidak baik pula.

Dalam kaitannya dengan pembentukan identitas bidang agama, peranan keluarga merupakan kunci sentral. Keluarga adalah lingkungan yang pertama dan utama bagi individu untuk melakukan interaksi dengan dunia luar. Orang tua yang menciptakan kondisi yang kondusif dalam mengasuh anak-anaknya. Gaya pengasuhan orang tua yang diterapkan terhadap anak, khususnya dalam hal penanaman nilai-nilai ajaran agama mempunyai hubungan yang erat terhadap eksplorasi dan komitmen dalam pembentukan status identitas remaja dalam bidang agama.

Menurut Hauser (dalam Archer, 1994), gaya pengasuhan orang tua yang bersifat enabling mempunyai karakteristik yang mendukung terhadap tumbuh kembangnya eksplorasi dan komitmen. Hal ini dimungkinkan karena gaya pengasuhan orang tua enabling mengandung kualitaskualitas seperti: orang tua melibatkan diri dalam pemecahan masalah anak, keikutsertaan dalam eksplorasi keinginan anak, dan memberi kesempatan kepada anak untuk mengungkapkan pandangan kepada anggota keluarga, ada ekspresi empati dan penerimaan terhadap semua anggota keluarga. Sedangkan gaya pengasuhan orang tua yang bersifat constraining mempunyai karakteristik yang menghambat tumbuh kembangnya eksplorasi dan komitmen, karena orang tua constraining tidak melibatkan anak dalam pemecahan masalah, tidak ikut serta dalam eksplorasi keinginan anak dan tidak memberi kesempatan kepada anak untuk mengungkapkan pandangannya kepada 
anggota keluarga, acuh tak acuh terhadap anggota keluarga, penilaian negatif yang berlebihan terhadap anggota keluarga dan cenderung menolak pandangan-pandangan anak tentang keyakinannya.

Grotevant dan Cooper (Archer, 1994) mengatakan bahwa institusi keluarga memainkan peranan penting dalam pembentukan identitas remaja, yaitu dengan cara membiarkan remaja mengungkapkan perbedaan-perbedaan pendapat dengan orang tua (individualitas) sambil mempertahankan rasa keterhubungan emosional mereka. Sedangkan menurut Waterman (1982), gaya pengasuhan orang tua dapat mempengaruhi ciri-ciri status identitas remaja, karena adanya perbedaan cara penyampaian harapan-harapan terhadap anak atau karena akibat proses identifikasi.

Menurut Marcia (1980), keterkaitan gaya pengasuhan orang tua dengan pembentukan status identitas adalah sebagai berikut: Remaja identity diffusion memandang keluarga mereka sebagai keluarga yang tertutup dan tidak akrab. Remaja identity foreclosure memandang keluarga mereka sebagai keluarga yang dekat, penuh kasih sayang dan selalu mendorong untuk menyesuaikan diri terhadap nilai-nilai keluarga. Remaja identity moratorium, memandang keluarga mereka sebagai ambivalen yaitu antara mau mengikuti kemauan orang tua dan usaha untuk otonomi. Sedangkan remaja identity achievement mempunyai keluarga yang mendukung diferensiasi mereka dengan siapa dapat memelihara penyesuaian.

\section{Metode Penelitian}

Pendekatan yang dipakai dalam penelitian ini adalah explanatory survey, dengan menggunakan metode korelasional, untuk menemukan ada tidaknya hubungan antara tipe gaya pengasuhan (sebagai variabel independen) dengan eksplorasi dan komitmen dalam pembentukan status identitas bidang agama (sebagai variabel dependen). Populasi sasaran adalah mahasiswa IAIN Sunan Gunung Djati Bandung Tahun Akademik 2000/2001 dengan sampel sebesar 200 orang yang diperoleh dengan teknik Two Stages Cluster Sampling dan disebarkan secara proportional alocation. Data dikumpulkan dengan Kuesioner Gaya Pengasuhan Orang Tua dan Pembentukan Status Identitas Bidang Agama yang dikonstruksi dalam bentuk skala bertingkat dengan empat opsi: selalu (SL), sering (SR), kadang-kadang (KD) dan tidak pernah (TP). Sebelum dipergunakan dalam penelitian, instrumen diuji coba kepada sejumlah mahasiswa (25 orang) Program Studi Komunikasi Penyiaran Islam (KPI) Fakultas Dakwah IAIN Sunan Gunung Djati Bandung dan menunjukkan bahwa instrumen tersebut memenuhi validitas dan reliabilitas internal yang memadai.

Pengumpulan data empirik dilakukan pada minggu ke-1 dan ke-2 bulan Desember 2000 dan selanjutnya data dianalisis secara 
deskriptif dan statistik inferensial dengan menggunakan teknik Korelasi Tata Jenjang Spearman dan uji signifikansi dengan ujit. Komputasi dilakukan dengan program STATS versi 2.6.

\section{Hasil Penelitian}

1) Ada hubungan positif yang signifikan antara gaya pengasuhan orang tua yang enabling dengan eksplorasi dalam pembentukan status identitas bidang agama pada mahasiswa IAIN Sunan Gunung Djati Bandung Tahun Akademik 2000/2001 $\left(\mathrm{r}_{\mathrm{s}}=\right.$ $0,506 ; \mathrm{p}<0,01) ; 2$ ) Ada hubungan positif yang signifikan antara gaya pengasuhan orang tua yang enabling dengan komitmen dalam pembentukan status identitas bidang agama pada mahasiswa IAIN Sunan Gunung Djati Bandung Tahun Akademik $\left.2000 / 2001\left(\mathrm{r}_{\mathrm{s}}=0,497 ; \mathrm{p}<0,01\right) ; 3\right)$ Ada hubungan yang signifikan antara gaya pengasuhan orang tua yang constraining dengan eksplorasi dalam pembentukan status identitas bidang agama pada mahasiswa IAIN Sunan Gunung Djati Bandung Tahun Akademik 2000/2001 $\left(\mathrm{r}_{\mathrm{s}}=\right.$ 0,701), namun derajat hubungan itu cukup longgar $(\mathrm{p}<0,05) ; 4)$ Tidak terdapat hubungan yang signifikan antara gaya pengasuhan orang tua yang constraining dengan komitmen dalam pembentukan status identitas bidang agama pada mahasiswa IAIN Sunan Gunung Djati Bandung Tahun Akademik 2000/2001 $\left(\mathrm{r}_{\mathrm{s}}=\right.$ $0,118)$.
Gambaran status identitas responden dalam bidang agama kaitannya dengan gaya pengasuhan orang tuanya dapat dilihat pada tabel berikut:

Tabel 1

\begin{tabular}{ccccc} 
& \multicolumn{4}{c}{ Gaya Pengasuhan Orang tua } \\
\cline { 2 - 5 } $\begin{array}{c}\text { STATUS } \\
\text { IDENTITAS }\end{array}$ & Enabling & \multicolumn{3}{c}{ Constraining } \\
\cline { 2 - 5 } & $\mathrm{f}$ & $\%$ & $\mathrm{f}$ & $\%$ \\
\hline $\begin{array}{c}\text { Achievement } \\
\text { Identity }\end{array}$ & 179 & 94,7 & 5 & 45,4 \\
$\begin{array}{c}\text { Moratorium } \\
\text { Identity }\end{array}$ & 4 & 2,1 & 2 & 18,2 \\
$\begin{array}{c}\text { Foreclosure } \\
\text { Identity }\end{array}$ & 4 & 2,1 & 1 & 9,1 \\
$\begin{array}{c}\text { Diffusion } \\
\text { Identity }\end{array}$ & 2 & 1,1 & 3 & 27,3 \\
\hline Jumlah & 189 & 100 & 11 & 100 \\
\hline
\end{tabular}

Berdasarkan data pada tabel di atas dapat dipahami bahwa dari 189 responden yang orang tuanya menerapkan gaya pengasuhan enabling terdapat 179 orang (95\%) yang telah berhasil mencapai status identitas achievement, 4 orang (2\%) masih berada pada status identitas moratorium, 4 orang (2\%) berada pada identitas foreclosure, dan terdapat 2 orang (1\%) masih terpuruk pada status identitas diffusion.

Sementara itu, dari 11 orang responden penelitian yang orang tuanya menerapkan gaya pengasuhan constraining, terdapat 5 orang (45\%) yang berhasil mencapai status identitas achievement, 2 orang (18\%) berada pada kategori moratorium, 1 orang (9\%) pada status foreclosure, dan 3 orang (27\%) terpuruk pada status diffusion. 


\section{Pembahasan}

Berbagai teori menjelaskan bahwa keluarga turut mempengaruhi pembentukan status identitas remaja. Menurut Grotevent dan Cooper (1985, 1986, dalam Archer, 1994), institusi keluarga memainkan peranan yang sangat penting dalam pembentukan identitas remaja. Selanjutnya Waterman (1982) mengatakan bahwa gaya pengasuhan orang tua diharapkan dapat mempengaruhi ciri-ciri status identitas remaja. Hal ini dimungkinkan karena adanya perbedaan cara penyampaian harapan-harapan terhadap anak-anaknya atau akibat proses identifikasi.

Berdasarkan hasil pengujian data secara empiris menunjukkan bahwa ada hubungan positif yang signifikan antara gaya pengasuhan orang tua yang enabling dengan komitmen dan pembentukan status identitas keberagamaan. Hasil analisis tersebut memberikan makna bahwa semakin sering orang tua menerapkan gaya pengasuhan enabling, maka akan semakin tinggi pencapaian eksplorasi dalam pembentukan status identitas bidang agama.

Fakta temuan di atas didukung oleh hasil analisis deskriptif (Tabel 1) yang menunjukkan bahwa dari 189 responden yang orang tuanya menerapkan gaya pengasuhan enabling ternyata terdapat $95 \%$ yang berhasil mencapai status identitas echievement dan ada 4 orang (2\%) yang berhasil mencapai status identitas moratorium. Sebagaimana dipahami, kedua golongan status ini merupakan orang-orang yang berkomitmen tinggi dalam rangka pembentukan status identitas keberagamaan. Hanya 3\% dari responden yang orang tuanya bergaya pengasuhan enabling yang mencapai status identitas yang memiliki elemen komitmen rendah, yaitu foreclosure dan diffusion .

Hasil analisis memberi indikasi bahwa semakin sering orang tua menerapkan gaya pengasuhan enabling, maka akan semakin tinggi pencapaian komitmen dalam pembentukan status identitas bidang agama.

Fakta temuan di atas didukung oleh hasil analisis deskriptif pada Tabel 1 yang menunjukkan bahwa dari 189 responden yang orang tuanya menerapkan gaya pengasuhan enabling ternyata terdapat $95 \%$ yang berhasil mencapai status identitas echievement dan ada 4 orang (2\%) yang berhasil mencapai status identitas foreclosure. Sebagaimana dipahami, kedua golongan status ini merupakan orang-orang yang membangun komitmen tinggi dalam rangka pembentukan status identitasnya dibidang agama. Hanya 3\% dari antara responden yang orang tuanya bergaya pengasuhan enabling yang mencapai status identitas dengan elemen komitmen rendah, yaitu moratorium dan diffusion.

Fakta ini dapat diterangkan dengan berpedoman pada kerangka teori yang ada yang menjelaskan bahwa orang tua yang menerapkan gaya pengasuhan dengan ciriciri enabling akan lebih memfasilitasi atau memudahkan bagi anak-anaknya untuk memantapkan komitmen status identitasnya. 
Hasil pengujian hipotesis menemukan bahwa gaya pengasuhan orang tua constraining, mempunyai hubungan cukup signifikan eksplorasi remaja dalam pembentukan status identitas dibidang agama.

Informasi lainnya yang mengacu pada hasil analisis deskriptif pada (Tabel 1) juga menunjukkan bahwa dari 11 orang responden yang orang tuanya menerapkan gaya pengasuhan constraining ternyata terdapat 5 orang $(45 \%)$ berhasil mencapai status identitas echievement dan ada 2 orang (18\%) mencapai status identitas moratorium. Kedua status tersebut menuntut aktivitas eksplorasi tinggi.

Hasil uji hipotesis ke-3 ini tampaknya melahirkan fakta yang kontroversial dengan konsepsi teoretik yang dipaparkan dari berbagai sumber. Fakta hasil analisis ini terlihat ada yang sejalan dengan konsep Marcia yang menyatakan bahwa remaja yang identity forclosure memandang keluarga mereka sebagai keluarga yang dekat, penuh rasa kasih sayang dan selalu mendorong untuk melakukan penyesuaian diri terhadap nilai-nilai keluarga. Kualitaskualitas pengasuhan seperti ini bertentangan dengan ciri-ciri constraining, oleh sebab itu data tabel 1 pada gaya pengasuhan ini hanya ada 1 kasus yang berstatus foreclosure. Remaja identity diffusion memandang keluarga mereka sebagai keluarga yang tertutup dan tidak akrab. Kualitas-kualitas ini mirip dengan ciri-ciri pengasuhan constraining dan dari tabel 1 tampak bahwa dari jumlah responden yang orang tuanya bergaya pengasuhan constraining ternyata ada hampir sepertinya terpuruk pada status identitas diffusion.

Fakta yang agak berlawanan dengan konsep Marcia adalah ditemukannya 7 kasus (hampir 64\%) dari responden yang orang tuanya bergaya pengasuhan constraining berhasil mencapai skor-skor eksplorasi di atas median ideal (achievement dan moratorium). Padahal, menurut Marcia (1993), orang-orang yang beridentitas achievement mempunyai keluarga yang mendukung adanya perbedaan-perbedaan dan memelihara penyesuaian-penyesuaian diri, suatu ciri yang berlawanan dengan kualitas pengasuhan constraining. Ditambahkan oleh Marcia, remaja yang identity moratorium memandang keluarga mereka secara ambivalensi, yaitu antara mau mengikuti kemauan orang tua dan usaha untuk mandiri.

Terjadinya kenyataan tersebut di atas ada kemungkinan karena remaja yang orang tuanya bersikap constraining di rumah justru malah melakukan perlawanan atau perilaku memberontak yang mendorongnya lebih sering melakukan eksplorasi di luar rumah, remaja mencoba untuk melepaskan diri dari keterikatan orang tuanya, remaja mencoba bertanya kepada orang-orang yang dianggapnya mempunyai kelebihan, sehingga walaupun di rumah memperoleh perilaku secara constraining tetapi di luar rumah ia memperoleh kesempatan bereksplorasi secara lebih bebas/otonom. 
Hasil pengujian hipotesis menunjukkan bahwa tidak ada hubungan yang signifikan antara gaya pengasuhan orang tua constraining dengan komitmen remaja dalam pembentukan status identitas pada bidang agama $\left(\mathrm{r}_{\mathrm{s}}=-0,118\right)$. Sebagaimana dipahami bahwa korelasi negatif yang ditemukan dalam kasus ini menunjukkan adanya arah hubungan yang terbalik antara gaua pengasuhan constraining dan komitmen dalam pembentukan status identitas bidang agama, namun dalam kasus ini, tidak cukup kuat bukti empiris untuk menerangkan keterhubungan kedua variabel tersebut.

\section{Kesimpulan}

Bertitik tolak dari temuan empiris dan pembahasan hasil penelitian ini, dikemukakan beberapa kesimpulkan sebagai berikut:

1) Gaya pengasuhan orang tua yang enabling mempunyai hubungan positif yang signifikan dengan eksplorasi dalam pembentukan status identitas bidang agama pada mahasiswa IAIN Sunan Gunung Djati Bandung Tahun Akademik 2000/2001;2) Gaya pengasuhan orang tua yang enabling mempunyai hubungan positif yang signifikan dengan komitmen dalam pembentukan status identitas bidang agama pada mahasiswa IAIN Sunan Gunung Djati Bandung Tahun Akademik 2000/2001;3) Gaya pengasuhan orang tua yang constraining mempunyai hubungan positif yang cukup signifikan dengan eksplorasi dalam pembentukan status identitas bidang agama pada mahasiswa IAIN Sunan Gunung Djati Bandung; 4) Tidak ada hubungan yang signifikan antara gaya pengasuhan orang tua yang constraining dengan komitmen dalam pembentukan status identitas bidang agama pada mahasiswa IAIN Sunan Gunung Djati Bandung Tahun Akademik 2000/2001.

\section{Daftar Pustaka}

Archer, L. Sally. (1994). Interventions for Adolescent. Newbury Park: Sage Publication.

Erkson, E.H. (1980). Identity and Crisis. New York: Norton.

Hurlock, Elizabeth B. (1993). Adolescent Psychology. Tokyo: Kugakusha, Ltd.

Hurlock, Elizabeth B. (1999). Developmental Psychology. New York: Mc. Graw-Hill.

Marcia, J.E. (1980). Ego Identity Status Interview Late Adolescent Form. British: Simon Fraser University.

Marcia, J.E. (1993). Ego Identity. New York: Springer-Verlag.

Mussen, P.H., Conger, J.J. Kagan, J. \& Huston, A.C. 1989. Perkembangan dan Kepribadian Anak. Edisi ke-6 (Terjemahan, oleh: F.X. Budiyanto, Gianto Widianto, Arum Gayatri). Jakarta: Arcan. 
Psympathic, Vol. I, No.1, 2008: 57 - 66 